\title{
Editorial
}

\section{Security, legitimacy and crisis in the aftermath of colonialism and in the midst of a pandemic: the role of state organs}

\author{
Lily Hamourtziadou
}

As a field, postcolonialism is influenced by the history, the impact and the aftermath of British and, more generally, European colonisation, the construction of collective identities, the production of knowledge and the representation of formerly colonised peoples. The Orient, as Edward Said argued, has been articulated and produced as a discourse through language and images. This discourse has arisen through institutions that hold power and authority, creating a geopolitical entity whose roots can be located in the context of Western dominance. This dominance not only created but also firmly established a relationship between the Orient and the Occident, a relationship marked by inequality, exploitation and criminilisation, which has come to be understood and accepted as a regime of knowledge and truth. This power relationship that enabled the colonising of the Orient still has implications now, in the aftermath of colonialism. 'Orientalism as discourse was not just an innocent attachment to colonialism; it was politically useful when colonial powers, such as Britain and France, were conquering their colonies. From this constructionist perspective, Said's argument, then, is that Orientalism is a system of knowledge and a configuration of power that actively made colonization possible by legitimizing colonial rule' (Koefoed \& Haldrup, in International Encyclopedia of Human Geography, 2020).

The discourse on the Orient and the Occident, and their relationship, was constructed, produced and utilised both in preparation of military campaigns and wars of imperialism, and also as justification for the occupation, exploitation and the crimes committed against the inhabitants of the Orient. The horrors of colonialism did not end with the end of colonialism but have persisted in the form of alleged counter terrorist measures, proxy wars, police brutality, coups, war crimes and repeated violations of international law by former colonisers and their security services and instruments. Old and new forms of subjugation and discrimination have led to renewed questions surrounding legitimacy and security in the 21st century. Colonialism may have ended, but post-colonialism depicts the continuation of representations, repression, resistance and racial/cultural discrimination. The legacy of the colonial era can be seen today in the streets, homes and prisons of the former colonisers, as well as in those of their former colonies.

Recent incidents in the United States and continuing activism, such as the social movement Black Lives Matter, are once again raising issues of police brutality, structural and racially motivated violence, of deaths as 'collateral damage', and of political, social and economic injustice at a global level. In a postcolonial world, security is arguably influenced by economic, political and social structures still understood in relation to imperialism and colonial rule, to a long history of oppression and injustice. Who continues to suffer its effects? Under what conditions is the use of force legitimate? In what conditions do Western publics support, condone or excuse police and military use of (often) deadly force? Finally, how can the police legitimately meet the demands of a multicultural society? 
This collection of papers and comments on the themes of security, legitimacy and crisis in the aftermath of colonialism offers insights, viewpoints and analyses on state accountability of police and military legitimacy, of human rights, and of the use of force and the abuse of power, from a variety of perspectives. The role of the state in security crises, through its security services, is explored in the areas of criminality, the war on terror, inequality within and between nations, and COVID-19.

In 'On the use of force', Hamourtziadou, Headech and Jackson address the issue of state power in the use of force at national and international levels, in violation of rules, laws and human rights that are overlooked when the victims' lives don't matter. The paper examines the use of force in policing and the use of force in military campaigns by the British state, both of which have resulted in civilian casualties. In doing so, the authors look at the principles of policing in England and Wales, the use of the prone position and, finally, the airstrikes and war crimes committed in the context of the War on Terror in Iraq, which are in violation of human rights laws and are crimes that have gone unpunished. As parallels are drawn between communities 'at home' and victims of war crimes abroad, it becomes clear whose lives don't matter.

In 'The global and national inequality faultlines: The economic dimensions of (in)security', Lawrence discusses inequality between and within nations as a major global faultline. Inequality within countries is increasing, he argues, with evidence of a growing concentration of income and wealth in the hands of a small number of very rich individuals and senior corporate executives on astronomical salaries and bonuses. These inequalities appear to be increasing during the COVID-19 pandemic, developing into threats to national and international security, to democracy and to human rights.

Thompson examines the relationship between right-wing populism and radicalisation, building on an understanding of postcolonial societal structures and identities that facilitate right-wing populism. With reference to Trump's presidency and Brexit, Thompson argues that right-wing populism has increased in Western societies, while also engaging with debates on the definition and causes of radicalisation to Islamic extremism in the UK. The author maintains that right-wing populism, along with counter-terrorism policy and the media, construct an anti-Muslim narrative, which fosters discrimination and, ultimately, leads to the social exclusion of Muslim suspect communities.

Azad's paper on domestic abuse within the South Asian community illustrates the prevalence of structural and racial inequalities in British society, using domestic violence, the concept of honour and coercive control in the South Asian community as a case study. In a post-colonial world, he claims, security is heavily influenced by economics, policies and social structures that are the continuation of those of colonial times. In his paper he argues that domestic abuse victims within the South Asian community, often overlooked by the police, are amongst those who continue to suffer from the legacy of colonialism, becoming victims of institutional neglect.

Carrillo's paper, 'Police culture and gender: An evaluation of police officers' practices and responses to domestic abuse', exposes police organisation as a substantially gendered setting, where manliness is valued and hierarchical structures are maintained. She looks at a variety of factors that can impact officers' behaviours, including lack of knowledge of the dynamics of the crime, misogynistic views, cultural beliefs and gender stereotypes, which are deeply rooted social norms. She argues that sexist views and discriminatory treatment are central components of police machismo, affecting the ability of the police to provide security, especially in a time of crisis. The COVID-19 pandemic and the lockdown that was imposed added an additional level of complexity to an already existing problem, requiring the right attitudes and skills to gain trust in the police and provide a sense of justice.

In 'Who's policing whom? A look into the policing responses to harmful practices and the role of civic society', Harrar explores police responses to harmful practices 
Vol. 8, No. 1, 3-6.

commonly perceived to be based on tradition, culture, custom and practice, religion and/ or superstition. In certain communities and societies these practices have been established for so long that they are considered or perceived to be part of accepted cultural norms. Having gone unchallenged for multiple generations, they have become 'normalised', which often makes it difficult to make the distinction between cultural/traditional norms and enforced harmful and controlling behaviour. The aim of the paper is to explore some of the key concepts that arose from discussions and which may go some way towards understanding hidden harms that exist in relation to honour and shame - in crimes/practices such as honour-based abuse, forced marriage and dowry violence. The role of affected communities is explored, as is how this can lead to a culture of self-policing by adopting a panoptic framework, before conclusions are drawn as to the future of policing in addressing these hidden harms.

Chalk's paper on 'Neoliberalism and personal freedoms during COVID-19' is set in the current health pandemic and consists of a comparative analysis of various countries' responses, reflecting how different countries are valuing their citizens' lives, health and safety. COVID-19 has put the global healthcare system under intense strain, he argues, and different healthcare systems have proven to be more effective than others. Neoliberal countries like the United Kingdom and the United States have proven to be the most vulnerable to a global pandemic, however the more socialist countries of Germany and New Zealand have fared much better. The authoritarian regimes of China and Vietnam have responded significantly better, though this was done at the expense of personal freedoms.

In 'Power, politics and policing: How the pandemic has highlighted fractures and fault lines in our society', Jarman looks at the application of power (through political controls), the issues of strain (pandemic and societal) and the police need for legitimacy. The principles of policing set out in 1829 , he argues, have a clear and resonating theme: the police are the public and the public are the police. Any move away from this position leads to reductions in legitimacy and effectiveness, and an increase in the use of force. The pandemic has been a time of concern about life and safety, felt universally. However, in the US and UK, data has emerged showing that people from BAME communities were more likely to die from the virus. The reluctance of governments to accept this and to protect the most vulnerable members of society has led to destabilised belief in systems. Terror Management Theory suggests that we build a series of structures that enable us to manage the threat of death, but when these are shown to be inadequate our self-esteem and worth are affected. As the risks to life become exposed, people become less likely to accept the added risk of racially targeted, and disproportionate, use of force. The images that came from the US during this time showed what Black people already knew - that in times of restraint officers' actions were not focused on the life of the person being arrested or questioned but were driven by other external events and fears. It was also clear that these events were systematic. When people do not feel safe from the virus, do not feel safe from crime and do not feel safe from the state, they will have increased concerns and perceptions of risk. When this is accentuated by seeing members of the majority elite being allowed to break the rules in a pandemic while their own community is disproportionately impacted by the use of police powers, there is a fear and energy produced that is ready to be directed towards a cause.

Duckworth's paper, 'Has the COVID-19 pandemic manoeuvred policing in England and Wales towards a single national police organisation?', discusses the operational effectiveness of the 43-force structure - the existing system of 43 forces in England and Wales, a system that the House of Commons Home Affairs Select Committee (HASC) called 'broken' in 2018. Through the lens of the COVID-19 pandemic, she asks whether the public health crisis has accelerated the drive towards further policing reforms and even a national police organisation. The question is considered within the context of national coordination arising 
from the pandemic, the impact on police legitimacy and lessons learnt from the unified policing models introduced in Scotland and the Netherlands.

In 'Policing the pandemic: The legitimacy of the police and the potential for civil unrest', Lewis comments on the potential for civil disorder that might take place if the legitimacy of the police is questioned, to a point beyond civil disobedience on a major scale, and suggests the need for the police to prepare for outbreaks of major disorder in 2021/2022.

In 'Policing the pandemic: Crisis without boundaries', Broadhurst points out that the primary role of police in managing major incidents is the preservation of life, the maintenance of order and the prevention of crime. To achieve this, they must have legitimacy and act in a way that engenders trust and confidence, allowing them to continue policing by consent. In countering the insecurity caused by the pandemic, the government has made decisions that would normally be unacceptable in a liberal, democratic society. It is the police that has borne, and continues to bear, the brunt of enforcing government policy.

Finally, in 'Policing the pandemic: An investigator's perspective', Foy addresses the need for a shared objective for policing in 2021 and beyond - delivering smart, agile, evidence-based tactics to support a flexible and investigative approach to deal with the risks and challenges of the new reality. The public, perplexed and anxious about their safety, he writes, expect and deserve nothing less.

The last word goes to Sarah Chevolleau, BLM activist and Director of Staffordshire Association for Black Lives Equality. 'Stay in your place!' is a comment on white privilege and on the disturbing fact that government-appointed servants are comfortable enough to kill innocent Black people in a world full of smartphones and CCTV, in the knowledge that an act of brutality upon a Black life will not be met with the same scrutiny as an act of brutality upon a white life.

\section{A note on the contributors}

This special issue has benefited from the diversity of its contributors, who are not only academics and students, but also police officers and activists. In addition, Deisy Carrillo is a Community Support Advisor, while Polly Harrar is the founder of the Sharan Project, a registered charity supporting South Asian Women in the UK who have been affected by abuse or persecution, and an advisory member for the Women's Interfaith Network. Lily Hamourtziadou, as well as being an academic, is the principal researcher and analyst of Iraq Body Count, an NGO that maintains the world's largest public database of violent civilian deaths since the 2003 invasion of Iraq, while David Lewis has led five youth justice delegations to China for the British Council and was a founding director of a youth conflict resolution organisation, 'This Way Up Mediation'. Peter Lawrence, as well as being a development economist, has been a lifelong political activist in movements such as AntiApartheid and CND, and in UK political parties.

\section{Reference}

Koefoed, L.M. \& Haldrap, M. 'Orientalism' in Kobauashi, A. (ed) (2020) International Encyclopedia of Human Geography, 2nd edition, Elsevier, p. 19-24. 